\title{
Decentralization as a Wide Social Subject - School System Policies and Autonomy in Post Communist Albania
}

\author{
Jani Sota, Assoc. Prof. PhD \\ Head Department of Sociology, Faculty of Education \\ "Aleksander Moisiu" University, Durres-Albania \\ E-mail: jani_sota @ yahoo.com
}

\section{Doi:10.5901/mjss.2014.v5n1p21}

\begin{abstract}
In post-communist Albania, decentralization and school autonomy has been and was a major policy objective of the Albanian state, which was a matter of debate among development specialists in the field of education, teachers and school administrators on which to reflect on the legal framework for reforming the education system. This research paper will try to illuminate fundamental issues: a) the meaning of the terms "centralization" and "decentralization" and their manifestations in education, contemporary perspective, b) Albanian state policy on decentralization and directions of its education after $1990 \mathrm{c}$ ) Albanian school autonomy during decentralization d) General aspects of decentralization and school autonomy in Academic and Vocational Education in Albania. The reform content of the education system in Albania after 1990, in this publication is stated that decentralization and school autonomy are two different problems, which do not necessarily mate. Decentralization without a great deal of autonomy and without the active support of the center may lead to the backward conservatory feelings and renouncing changes. School and local autonomy are incomplete if actors and clients do not play a greater role in decision making. Delegation of responsibilities at different levels (regional, local, school) is a complex process, in which case the school will have more responsibility in the field of teaching, administrative and financial responsibilities and be transferred to the regional level or local, then there will be a potential source of conflict.
\end{abstract}

\section{Introduction}

Schools have a mission to provide an education to all individuals who give them the knowledge and competencies necessary for the flourishing of their full intellectual potential, allowing them to exercise their rights and fulfill their duties as free citizens in a democratic society, developing their skills, transmitting values, cultivating their character and attitudes (behavior) of them.

For society, education represents an important integrating force that recognized value, continuity and preserves its internal cohesion. It is an important dimension of quality of life, a need for continued democratic development and support of political and social stability. It is an important premise for preliminary economic growth and the ability to succeed in a competitive world (Lulja, 2009).

Within the scope of the overall transformation of our society towards the overall democratization of social relations, economic transition and preparation for integration into European structures, the democratization of education and education for democracy play an important role at all levels and for all participants (Haecht V. A. (1998). Democratization of education system, its institutions and the educational process, is at the same time another purpose and direction of educational policy towards decentralization of education and increasing school autonomy.

By definition of Michihiro Kandori: "Means decentralization and distribution of authority by passing a higher level of government to a lower level" (Kandori, 2008). Being limited only to the sphere of education, Chris F. Kemerer gives this definition: "decentralization, support from community schools and local control are all names that indicate the transfer of authority and responsibility for the financing and management of schools, a sub-national organization"(Kemerer, 2007).

Forms of this transfer come in several types: non-concentration - the transfer of authority to lower levels, dependent on the central government; delegation - the transfer of power to run public bodies or publicly governed; devolution - transfer of local government bodies (sub-national) and privatization - the transfer of authority to private firms or individuals.

Centralization - as the expression of a rational direction and coordination is concomitant of any organization or institution specific state. It can not think of any country, organization or enterprise without a center that takes the most important decisions that organizes, directs, and coordinates and controls, which provides operation as a whole and 
resolving issues at the lowest (basic level) that can not be solved.

For the education system, "centralization as a form of state administration and control has its role to ensure the realization of the least apt to equality of opportunity for education" (Ladd, 1996). It enables supply and organization of a system of free public education at least up to the level of compulsory education. The quality of education provided is intended to be equal and identical from one school to another and one that is officially recognized by the state and the needs of the relevant age group. Through centralization, society can better decide on rationalizing public spending and objectively use resources effectively at the national level. This type of decision-making is more useful when tolerated more uniformity and equality than variation, and the whole education system is at risk.

Centralization makes it possible to maintain state control and supervision of the school system as a whole and to verify to what extent satisfied or met the national standards of student achievement. The state plays its role as a central regulator not only for the educational service that provides schools, not only as the guarantor of justice

Decentralization prevails when more flexibility is required to provide educational services at the local level, to be closer to the customers of education, recognizing the needs of these schools. The goal of decentralization is to improve the work of the schools, believing that the functioning of the education system can be improved if better meet local needs the needs of users and whether education increases the role of actors that provide educational process (Sui, 2005).

Anne Van Haecht on decentralization gives us three arguments, which are: redistribution - according to this argument, all the necessities needed to participate in the decision-making process, the efficiency - all levels should participate in the decision-making process, as well as learning culture - which calls for more awareness about the differences that exist between local communities. It is clear for example the economic and cultural differences should be kept in mind when designing school curricula, as part of decentralization of curriculum (Haecht, 1993).

But the English Harold $\mathrm{H}$. Weiler in his "Decentralization in Educational Governance: an Exercise in Contradiction", gives two other arguments for decentralization as:

- Managing social conflict. Decentralization allows the state to distract sources of conflict, distributing responsibilities.

- Seeking compensatory legitimacy. The right to have the community to express their identity (Weiler, 1990).

State decentralization gives way even when not everyone wants to take responsibility for unforeseen developments in certain areas. For this, by granting local authorities more powers in terms of increasing authority, it also leaves them the responsibility, partially freeing themselves from the moral burden of non-success or failure.

The report between centralization and decentralization of education that exists in a country is determined by the set of rules (formal and informal) which affect interactions between actors (individuals or organizations) in insurance, manufacturing and consumer education services (Murphy et al., 1998). These rules define the actions and consequences of decision-making decision. But these actions are affected naturally by the consequences of positions and incentive interests of stakeholders at different levels.

Centralization and decentralization are two integral part of a balance that can not exist by having only one side of the coin. Decentralization in education is a trend that is clearly evident in Europe. In countries where the education system is decentralized, more emphasis is placed on school autonomy, to ensure that national centralization will not be replaced by local centralization. While in decentralized countries such as England Recentralization trends (in the curriculum, control and evaluation) are associated with decentralized measures (prompting local authorities by giving a part of direct responsibilities to schools (UNDP, 2004).

There are two reasons that make decentralization, especially with respect to autonomy of the school, which tends to be a favorite.

- Ensuring the effectiveness of the school, prompting the responsibility of each academic institution to its customers, primarily to students and parents.

- Ensuring public participation in the management and functioning of education.

People's participation in the formulation, determination and implementation of development policies in all areas is an important principle of social life in democratic countries, one of the main indicators of the existence and functioning of a democratic system. In this context, it should be noted that the movement towards decentralization is affected by the need to democratize the country life and to make schools more effective and efficient.

As noted above, one can rightly say that decentralization is a dominant trend across Western Europe and its usefulness is not only in the field of education, it is an opportunity to support local initiatives and individual. It conveys a radical evolution of the organization of society. 


\section{Albanian State Policy on Decentralization and Its Directions in the Field of Education since 1990}

After the collapse of communist dictatorship and the establishment of democracy in Albania, after 1990, decentralization and school autonomy are among the most important education system issues of all segments related to its activity. They are made from the most common terms in the current debate on the reform of school education and Albanian. Based on the fact that modern strategies consider development and school education as important elements of the overall development, "currently identified some of the objectives associated with the decentralization of the education system, dealing more with: educational opportunities, quality of democracy's education and the educational process" (Memushi, 2003).

In post-communist Albania, the goal of education contributed to the formation of a free and responsible personality. For society, school education represents an important integration force that recognized its value, continuity and preserves its internal cohesion. It is an important dimension of quality of life, a need for a continued democratic development as important for economic growth and the ability to succeed in a competitive world.

To ensure effective leadership and management of the education system is seriously important to understand the inclusion of interested persons related to education, the recognition of local needs, ethnic and cultural, as well as decentralization of leadership and management system. This process should be conducted in parallel with the administrative decentralization of the country, in conformity with the local government and this requires:

First, the concept of decentralization of education management, by transferring responsibilities to managers of education services in the counties, prefectures, municipalities and schools. The main challenge in the development and implementation of decentralization and democratization policy for dealing with: determining clear roles, establishment and capacity building at all levels, transparency and accountability in local and central authorities and distribution of information through the processes and procedures suitable.

The second is, redesigning the finance in a decentralized system, including a scheme of the new formula for each student in order to improve the efficiency of the school budget.

The main directions of the Albanian democratic state policy connected to the decentralization process at the system level of education requires: inclusion of all persons interested in adaptation planning and policy educational reform, through a process of consultation and public discussion; legal changes will facilitate decentralization of management and decision making with internal mechanisms responsible; establishment of a National Council of Education, as an independent body consisting of experts and representatives of civil society (non-governmental sectors, the economy, culture and science); development of mechanisms to combat exclusion and abandonment of school, which relate to separate programs to encourage minority population to attend school, ranging from preschool age, involvement and sharing of programs for children with physical disabilities and special needs, insisting on flexibility and transparency in the education system: greater mobility of students horizontal and vertical (change level / type of school) and teachers (Training them for teaching multidisciplinary or interdisciplinary subject). It is important that all educational institutions for training should be mandatory full disclosure of public and permanent conditions of attendance, programs and services they offer, regarding reporting for their achievements, making possible and support formal and informal education system, which has to do with the official approval of developments related to programs from non-public sector, licensing of schools / programs in accordance with quality standards, creating an "open market with stable programs and services", which must necessarily be subject to official approval / licensing and open to the public and the institutions or persons interested in education, development of an accreditation system for teachers, instructors, inspectors, consultants, managers, etc., and a licensing system for schools, programs, etc.; pedagogical supervision service with professional development system; support for an expansion of educational programs and services from participating institutions and especially encouraging in some parts of the education system (e.g. Preschool education, vocational education, etc.), through specific projects and making reform of international experiences, stimulating cooperation between and through schools, including mobility of students and teachers, common application software, enabling the combination of programs in various educational institutions; and improving the quality of education in the formal and informal system (improvement of working conditions, professional development of teachers and other employees, modernization of the educational process, and the real possibility of education for all).

\subsection{Decentralization policy level for the curriculum}

Decentralization policy strategy at the level of the curriculum, among others, was rightly directed on some key issues, such as: introducing curriculum reform, establishing knowledge and core competencies, instead of software-based 
content for specific subjects such as decision-making on the percentage differences between the commodity required by elective and optional subjects, depending on the age (e.g. $20 \%$ in the higher grades of compulsory education, $30 \%$ in secondary schools) stimulation, adaptation and development based curriculum in schools and classrooms, as well as special projects and teacher training, especially for interdisciplinary courses and modern methods of work in education, in the drafting of professional development programs for teachers of the required training associated with: implementation of policies and collaborative interactive teaching / learning, education etc. democratic methods.; establishing partnership relations with students and parents; development of communication skills and understanding of successful non-violent conflict resolution; incentives of self-reflection and professional criticism, evaluation and redrafting the existing curriculum at all levels so as to comply with human rights and children's rights, democratic values and processes. This refers to the content of specific courses as well as teaching methodology, and determining the criteria and standards for the harmonization of programs and textbooks in accordance with human rights / child rights and democratic values.

\subsection{Decentralization policy at school level}

Policy directions at the decentralization process in the school / learning process was necessary to be oriented towards: enabling local community participation, under the legislation, participation of teachers, students, parents in running the school / institution and decision making related to the content and organization of school life; stimulating and establishing systematic work of school transformation into "open institutions," which will respond to the current needs of students, staff, parents and the wider local community, through "development school projects": developing the requirements for the autonomy of school boards through schools and increasing their responsibility to the local and central authorities educational school development funds and "development projects to school"; creation and improvement of democratic procedures for the recruitment of teachers, directors and board members schools; Assistance and specific training programs to increase the powers and responsibilities for administration officials and managers in school, municipality and region, support for the development of democratic restructuring of teachers' trade unions, organizations and students bodies; encouraging extra-curricular activities, enabling the introduction of alternative textbooks and alternative sources of information.

\section{Albanian School Autonomy - An Expression of Its Decentralization;}

Albanian society in current years has entered into a complex process of decentralization, as inevitable aspect of economic disposition. Publications for decentralization, especially for Eastern European countries in recent years have increased in progress but not found the magic formula which provides solutions for any situation or place. In this context, the decentralization will be featured in Albania characteristics and its implementation step by step in transfering power from a higher level of government to another level would be put together.

Based on global experience, there is designed a "strategy of decentralization and local autonomy" of the National Decentralization Committee. The material recognizes the Constitution of the Republic of Albania and the European Charter of Local Autonomy, which our parliament has ratified. This material is also a basic document for all central and local bodies of the country. In this context, it creates space for real implementation of decentralization, based on the law "On the autonomy of school" as the most important basic unit of our educational system.

Providing real autonomy is not a simple thing. This requires, in addition to competence, clearly define responsibilities and to whom they appear. In governmental concept is estimated that "decentralization increases the effectiveness of the school, because of a better knowledge of the conditions and requirements of the community and create a structure based on shorter chains responsibilities, enabling improved quality of services providing to the community and increased accountability of local representatives" (Xhepa, 2007).

In this context, one can rightly question for discussion the question: can the Albanian schools currently take responsibilities related to school autonomy?

In many respects, it has options and a good portion of the responsibilities. Increased school autonomy depends on a number of other factors, which are mainly economic and conditional on further developments of the country, it also depends on new positions and organizations outside the school authorities, who are directly or indirectly interested in (Rrapo, 2002).

School autonomy has to do with the interaction between the internal structure and external structures, associated with and is directly concerned with the school.

What were the internal structures and external to the school acting in the Albanian communist dictatorship in the 
years 1945-1990?

The internal structures of the school in the years of the communist dictatorship were:

The school administration. For small schools there were only directors, and large schools of several deputy directors, who realize, in addition to teaching the 20 hour check in month (Ibid.); Educational Council. It included all teachers and some students who formally belonged to the school (Ibid.).

Commissions for subject evaluations. Depending on the size of the school, the school functioned according to major schools and some schools when they were in a small number of students (lbid.). Later, these were replaced by Formats, who were teachers of classes and conducting training reduced by profiles for several area schools.

Districts directories for extracurricular activities (Ibid.).

Youth organizations and the pioneer (lbid.).

Organization for teachers: Party Organization, the Organization of Professional Union; Organization of Women and Youth Organization and the Committee of Parents (Ibid.).

All these ingredients were the internal structure of the communist school, which in one way or another dealt with learning problems, behavior of teachers and students etc. This structure was accountable to the school department and the organization of the party.

Extracurricular structures in the school in those years were:

Department of Education, which systematically controlled the overall operation of the school and teachers. Note here that the teacher should have had the five notebooks, which should be documenting every activity in school, up to work in an agriculture brigade.

Pedagogical Cabinet was the main teacher training section but most of the time used by its employees for education section control.

Institute of Pedagogical Studies, which mainly dealt with various studies, dealing with the problems of teaching, and after 1980, was committed to the development of programs and textbooks for most subjects.

Ministry of Education according to an annual planning controlled for two to three school days the use of control and direct observations in class. In conclusion, the team of the Ministry of Education gave the district level inferences, where schools and teachers receive due credit check compared with other schools.

Central and local authorities had the right to exercise control in school. They were: Party Committee of Experts; Professional Union; Women Organization; Youth Organization and Control of workers and agricultural workers.

Organizations and bodies above controlled departments of schools and teachers, mainly in certain political moments, or particular event. Also, they observed education for these figures to school, even teachers diary.

After 1990, after establishment of democracy in Albania, reforming the education system or connecting with "a series of issues among which the most important were: governance system, education funding, the setting authority of school program (curriculum) and the adaptation of this authority and procedures for the establishment of schools , teacher professional development, supervision and management, funding and curriculum implementation, and internal and external evaluation" (Memushi, 2003).

Based on the experience of developed European countries in transition and Albanian school experiences, through consultations with all groups of experts in the field of education, were identified "Four main levels of government education as central, regional, local and school".

At the national level, it was established step by step: definition of development strategies, opinions or draft legal acts, the definition of core curriculum, the annual allocation of funding, decision making and implementation of external evaluation, provision of pedagogical inspection, increase of international cooperation, the definition of professional standards and modalities of career, licensing for schools and educational institutions, licensing procedures based on skills and competencies for teachers and support staff of experts not involved in teaching (teachers, psychologists) creating a system of national educational information.

At the regional level, attempts were made to transfer the powers such as the management of educational institutions, initiatives and proposals for school funding and implementation of their participation in the appointment of directors of regional schools, organization and implementation of teacher training.

At the local level, there were efforts on: initiating and proposing the creation of compulsory education, the establishment of pre-schools, participation in selection committees for appointment of directors and those preschool education compulsory, network administration and preschool education compulsory inspection.

At the school level, there were efforts towards: the leadership and management of school curricula specifications, defining additional content of lessons, assessment of internal selection for alternate texts, preparations for the School Development Plan, training teachers involved in teaching, collaboration with the local community and people with 
interests in education (NGOs) (Ibid.).

The Ministry of Education in Albania included in the new structure related to the decentralization of education management, intends for these transfers "to take place gradually being convinced to greater accountability for local communities and capacity required from local governments" (Ibid.).

\section{General Aspects of Decentralization and School autonomy in General Education in Albania - From Policy to Practice}

Now is known that the Ministry of Education and Science has undertaken some reforms related to school autonomy, which have basic directions that correspond to the respective fundamental directions of the Strategy for Pre-University Education. Some of the main aspects deal with: reorganizing education system in line with the need for an effective contribution to economic development, modernizing or reorganizing education for a greater contribution to the democratic development of the country, and modernizing or reorganizing education for a greater impact on future European integration of the country.

\subsection{In the area of Curriculum}

The reform of the so-called "Altertekst" evolution closed down for several years the designing, publishing, printing and distribution of textbooks, curricula bringing the standards of the time. Now, the teacher selects text file, used during the school year, in a text menu on that subject, which was approved by a central body of text evaluation. This has to do with the "expansion space at the school level decision-making, starting to influence the direction of improvement of the quality of textbooks and increased accountability to student achievement" (SOROS, 2007).

Despite the reforms, the problems encountered, particularly in the area of curricula, where the teacher still skewed more attention to students of "good" achievement. Recently in Albania, Secondary Education seems more elitist and viewed as a bridge in preparation for students to continue further studies (Ibid.). With all the emphasis of the curriculum, still students with low achievement know less than might expected.

It should be noted that, despite recent measures taken by the Ministry of Education in terms of liberalization in favor of the school curriculum and teachers of the subject, the teacher still considerably, especially, at regional and local level, is conceived as a conductor of set curriculum mainly from central governance having limited opportunity in decision-making in the pace of learning and teaching, as well as subject matter. Close decision-making space reduces the potential for teachers and reduces academic growth and personal development of students.

Reform of the "10\%", gives teachers another opportunity to make decisions in teaching and learning process. According to it, a subject teacher may develop a chapter or an online course with less or more classes as defined by the object program and professional freedom that is at the limit $(-10 \%,+10 \%)$. This reform is a the last step of teaching and learning, text-based, student-centered strategy, places the responsibility of the teachers for the text in student achievement for a chapter or an online course (Ibid.).

Reform of "Free hours", is complex and opens wide possibilities for curriculum at school level or, in other words, school autonomy in curriculum. According to it, most of the so-called "free hours", which generally distinguish syllabus, taken these together for a class, is the school decision how to use them, given the interests of students and their parents, the trends and opportunities the teachers (Ibid.). Also important is the interests of the wider school community and the local government.

\subsection{In the financial area}

School autonomy in public university education is inextricably linked with financial autonomy and its decision-making skills in the management of funds available for education.

Within the decentralization process for reform and public education in university it is determined that "public university education is a common feature of central and local government" (Ibid.). It must be said that recently in our country by the central government some effective measures are being taken in the financing component, which have no small impact in increasing the effectiveness and quality of school academic work.

Decentralization in planning, the distribution and use of funds at the local government, municipalities or district councils, investment, funds and facilities maintenance and service to educational institutions is a very effective achievement in financing associated to funds (Ibid.). Also, effective can be mentioned the measures related to "raise the 
salaries of teaching staff in public pre-university education, the creation of opportunities for the development of economic activities by budgetary institutions in general, including schools, etc." (Ibid.).

If considered the amount of funds used in the general framework in the country can be found that although not met public funding of university education without a doubt from year to year has increased. This is as a result of increases in funding from the state budget, but also because in recent years has expanded participation of local governments in financing this sector. Meanwhile, foreign and domestic donors' contribution remains constant.

Reform of the "Library book", is one of the most important steps taken by the end times which a separate fund from the state budget is specifically listed for school library devices. Distribution of this fund schools follow the formula "per students", while, according to a standard procedure, the teachers is who decide which books should the school be equipped with (Ibid.).

Reform of the "Means of learning" closes the not transparent situations and long-standing abuses and ensures that the principle of equal opportunity between schools. According to this reform, "each school's instructional predetermined fund, according to the formula "per students" sends a list of learning resources that can be provided to the school, together with the respective reference prices" (Ibid.). According to a standard procedure, the school sets itself the teaching tools that it needs and specifies their respective number.

\subsection{In the area of management}

Currently, public university education in local government dependence relates to the administration of schools, with management services to its financing.

Dependence of the school by the devolved central government level Regional Education Directorate (RED) is about the content, software, texts, appointments and qualifications of teaching staff, including instructional leaders and relevant teaching.

Reform reconfiguration of the school board, is one of the measures by which is expected a strengthening of school autonomy in general. According to a special instruction of the Minister of Education and Science, school boards began to function in the academic year 2007-2008, with a fairly changed status from existent (Ibid.).

\section{General Aspects of Decentralization and School Autonomy in Vocational Education (VE)}

Post-communist Albania generally inherited a system of centralized Vocational Education with limited autonomy. Key issue was the question of the positions (Who decides? For what decides? When? How decides?). In this regard, it was ascertained confusions about the direction of intervention: decentralization (power transfer in decision-making from central to regional), devolution (representing the local organization with headquarters at regional / local level), increase autonomy (self-acting growth opportunities for schools).

However, in the state of Albanian today it can rightly be said that transformative interventions at school level pilot operated, touched the step changes in the education system. It is observed in post-communist Albania the "discordance between what "formalized" and what "applied" (Ibid.). But can mention the fact "of a lack of awareness and competence to increase school autonomy" (Ibid.). This was a result of lack of experience of educational directors after the 1945-1990 dictatorship experience operating model of extreme centralization and politicization of Albanian school.

In the area of Curriculum, VE appears in a centralized design but detailed in implementation. Schools and teachers have limited freedom to adapt the curriculum in line with regional developments and opportunities of schools. There is a lack of electives and "free hours" in the curriculum.

Officially, it is said that at vocational schools greater opportunities appear for textbook selection but has not yet started publishing VE textbooks. Generally, there is lack of capacity-development curriculum in school. National level I regional aspects are not included in the curriculum. Currently is being piloted "two-tiered" curriculum in VE: Maincurriculum (compulsory standard central) and school curricula (curricula compiled in school-based curriculum framework, the regional specificity and profession opportunities in real school).

In the financial area, according to Albanian state laws currently in VE, sources of funding are: the state budget (central and local), income from operations, contributions of partners (donors, sponsors). Referring to the legislation in force, it can be said that "there are three levels of income distribution in VE: Ministry of Education and Science (MES), municipalities and vocational schools" (Ibid.).

It should be noted that "national" vocational schools have no involvement of municipalities / communes in their financing. Also, RED and EAs are not included in the financial aspects of AP. 
Vocational schools generate income by selling products and services, but there are legal disputes and accounting management of these revenues. School autonomy in the use of income is low. The school has the right to negotiate with the Ministry of Education and local government budget items. However, the flexibility of the budget (transfer between items) is low.

\subsection{In the field of management}

"National" vocational school are currently subject to direct MES regarding the opening / closing of the school, the appointment, financing, learning profiles, curricula and textbooks.

"Non-national" vocational courses are depending on the local government (investments) and the RED's (and the appointment of staff).

Professional school principals are responsible for the performance of primary school, but have limited decision. In this context, they are also managers / administrators, and educational leaders in school activities (dual role).

In these school boards there are currently formal mechanisms with very low impact on the vocational school that does not guarantee inclusion of social partners in decision-making.

Involvement of teachers (teaching council) and the students in decision-making is limited.

\section{Conclusions}

While decentralization continues to be a major policy objective of state, there is the issue on which develops debates among specialists in the area of education, teachers and school administrators on which to reflect on:

- Decentralization and school autonomy are two different problems, which not necessarily mate. In postcommunist Albania, decentralization without a great deal of autonomy and without the active support of the center can lead to the conservative mentality and quitting from changes.

- School autonomy and local autonomy in Albania, will not really be complete if the users, clients of schools fail to play a greater role in decision making. For this, it is important to expand their opportunities to choose and shape in opinions. It is not only to give more power to users of beneficiaries but also to make the system more flexible.

- Among the arguments of decentralization and school autonomy there are those that are difficult to reconcile. Thus, the objective of economic efficiency agrees with difficulty with the diversification of curricula and the need for a close interaction with the local community in the areas of economic and demographic decline. In addition, social and economic differences are real and tangible at the local level than at the national level and these created problems in ensuring justice in education.

- Delegation of responsibilities at different levels (regional, local, school) is complex process. If the school would have more responsibility in the field of teaching, administrative and financial responsibilities will be transferred to regional or local level, then there will be a potential source of conflict.

- Autonomy of the school process is not easy anywhere. In Albania, there are still certain feelings from teachers, a distrust of the school management principle as an institution, in competition with other institutions in a free market. In this context, the debate on centralization-decentralization issue has to do with a political debate, connected with the option of liberalization and democratization.

a) On the one hand, in view of the entrepreneur model, it is time for academic institution to be viewed as an institution able to ensure the quality of its product without external help. This conviction is the source of policy option that favors privatization, decentralization and compensation.

b) On the other hand, educational institution should be regarded as a social service institution, as the state being the guarantee and leading national education administrator. This is the model that prevails not only in Albania but also in Europe. This model is based on principles of equal opportunities and education for all. Schools, according to this conception, are first and foremost public institutions, open to all and the rights of administration belong to the state.

For democratic countries, is important the fact that the state is the guarantee and the main respective and only belittled for a modern educational systems. In many cases, historically, the state shares this responsibility more or less, to a certain time, with others who are interested in school. Furthermore, note that school systems themselves are bearers of a relative autonomy in the exercise of their functions. 


\section{References}

Weiler, H. H. (1990), Decentralization in Educational Governance: an Exercise in Contradiction , London, pp. 236.

Haecht V. A. (1993). Décentralisation Centralisation des Systèmes et en Europe éducatifs: tendances et contradictions, Strasbourg, pp. 198-199.

Haecht V. A. (1998). "Les politiques éducatives, figure exemplaire des politiques publiques ?", Education et sociétés, Paris, I.N.R.P., Bruxelles, De Boeck, 1998, n¹, pp. 21-46

Sui, C. H. (2005). "Effect of School Climate on Student Mathematics Performance: The Case of Hong Kong", Educational Research for Policy and Practice, 4, pp. 47-64.

Kemerer, F. C. (2007). "Project Management", discussion leader, GaliLead Program, Carnegie Mellon University, Pittsburgh, PA, June 2007.

Kandori, M., Serrano. R., Volij, O. (2005). 2008. "Decentralized trade, random utility and the evolution of social welfare," Journal of Economic Theory, Elsevier, 140(1), pp. 328-338, May.

Ladd, H. (1996). Holding schools accountable: Performance Based reform in education, Washington, DC: Brookings Institution.

Lulja, E. (2009). Thoughts on Education Reform, Tirana:"Filaret".

Memushi, L. (2003). School reform, process and strategy Pedagogical Research Institute, Tirana

Murphy, J., Hallinger, P. et al. (1998). The administrative control of principals in effective school districts", Journal of Educational Administration, 81, pp. 175-181.

Rrapo, S. (2002). School autonomy - an expression of its decentralization, Pedagogical Journal, 2, Institute of Pedagogical Studies, Tirana, pp. 24.

SOROS. (2007). On the decentralization of education and increase school autonomy", published by the Open Society Foundation for Albania "Soros", Tirana

Temo, S. (1984). Education in the People's Socialist Republic of Albania, Tirana: "November 8".

UNDP. (2004). Promoting ICT for Human Development. A Pioneering Regional Human Development, Report in Asia in 2004: Realizing the Millennium Development Goals (Retrieved from http://www.apdip.net/projects/rhdr/resources/PDF on December 2009

Weiler, H. (1990), Decentralization in Educational Governance: an Exercise in Contradiction , London, pp. 236.

Xhepa, N. (2007), Steps towards decentralization of the education system, Pedagogical Journal, Institute of Curriculum and Standards, 1, Tirana, pp. 73. 
